\title{
ELEMENTE TEHNOLOGICE DE UTILIZARE A CAPCANELOR CU LUMINĂ PENTRU MONITORIZAREA ŞI COMBATEREA INSECTELOR DĂUNĂTOARE
}

\author{
Gorban V., Voineac V., Maievschii V. \\ Institutul de Genetică, Fiziologie şi Protecţie a Plantelor al MECC \\ E-mail.vgorban.alimeco@yahoo.com \\ https://doi.org/10.53040/9789975347204.21
}

\begin{abstract}
Low efficiency of plant protection means is explained by the lack of a centralized forecasting system for the terms to carry out protective measures, lack of modern methods of obtaining primary data for making up reliable short-term forecasts for the development and spread of pests in agricultural agrocenoses.

During last years investigations cowering the elaboration of new systems of integrated plant protection became more active by utilization biorational means of plant protection, and electro optic installations. A great attention is accords to elaboration and selection of sources- attractants and new electro optic structures whice must show a high attractively due to a specific irradiation spectrum and, thus, provide a maximum trapping of harmful insects.

Application of the light traps is a more perfect method for phenology investigation of many important, in an economic aspect plant pest, and results of insects gathering can by used for elaboration short-term prognoses of insect pests development for rendering more precise the terms for craning out of protection measures. Further the light traps for insect can be used as an independent mean for plant pest combating.

In combination with other methods to combat the use of light traps significantly reduces the number of flying pests, and thus caused them harm.
\end{abstract}

Keer volds: fototaksis, spectrum, attractant, light traps, optical radiation

\section{Introducere}

În sistemul de protecţie a plantelor de dăunători sunt cunoscute patru grupe principale de metode: agrotehnice, mecanice, biologice şi chimice [1]. In ultimii ani sunt efectuate cercetări pentru elaborarea metodelor noi de protecţie bazate pe utilizarea diferitelor tipuri de energie electromagnetică numite electrofizice [2].

Datorită unor dezavantaje ale fiecărei dintre metodele cunoscute de protecţie a plantelor, este rezonabil ca ele să fie folosite într-o combinaţie optimală. Pentru aceasta se aplică sistemul de protecţie integrată, care prezintă un set de metode raţionale şi instrumente, la care se iau în considerare factorii naturali de reglementare a mediului şi să respectă constrângerile economice şi ecologice . În acelaşi timp se estimează pragul economic de dăunare, care este caracterizat prin valoarea minimă a numărului populaţiei de dăunători pentru care cheltuielile aduse la măsurile de combatere sunt recuperate prin venitul de la realizarea producţiei păstrate de o calitate mai înaltă.

Protecţia integrată a plantelor presupune și o tactică specială de utilizare a mijloacelor tehnice elaborate pentru a obţine informaţii despre indicilor numerici ai populaţiilor, atât de insectele dăunătoare cât şi benefice în agrocenoze, raportul numeric dintre ele și perioada de dăunare a celor dăunătoare etc. Având astfel de informaţii se pot lua decizii întemeiate cu privire la necesitatea efectuării măsurilor de protecţie şi planificarea termenilor de aplicare 
a acestora. În acest caz, accentul se pune pe metodele selective, care acţionează numai asupra insectelor aflate în faza cu potenţial dăunător. Acest lucru asigură conservarea maximă şi aduce la îmbunătăţirea mecanismelor naturale de control a insectelor. Eficacitatea sistemei de protecţie integrată este în mare măsură determinată de calitatea de monitorizare a dezvoltării dăunătorilor, efectuarea căreia are o bună perspectivă prin utilizarea dispozitivelor cu surse de lumină ultravioletă cu lungimea de undă de 350-370 nm

Argumentarea elaborărilor. Pentru a efectua supravegherea cu scopul de a semnala apariţia dăunătorilor principali ai culturilor multianuale, în special a viermelui mărului şi prunului, este rezonabil de a elabora noi tehnologii şi metode de protecţie a acestor culturi, folosind în sistemele existente dispozitive electrooptice - capcane cu lumină ultravioletă. Tehnologia elaborată pe baza de utilizarea a dispozitivelor electrooptice va permite de a minimaliza utilizarea produselor chimice (reducerea numărului de tratamente chimice de planificate de la nouă la trei sau patru, sau complet de a le reduce). Utilizarea capcanelor cu lumină la protecţia plantelor vă permite să se obţină producţie ecologic pură în acelaşi timp îmbunătăţind calitatea fructelor la nivelul standardelor existente.

Modul de capturare a insectelor dăunătoare şi aplicarea, cu acest scop, a capcanelor cu lumina, la baza cărora este pus efectul de atracţie de către sursa de radiaţie ultravioletă a insectelor dăunătoare, este important pentru identificarea speciilor de dăunători, în circumstanţele specifice ale câmpurilor protejate.

\section{Modul şi schema tehnologică de utilizare a capcanelor cu lumină.}

Modul şi schema tehnologică de utilizare a capcanelor cu lumină depinde de scopul pentru care ele sunt utilizate. Pentru efectuarea evidenţei cu scopul de a semnala apariţia principalilor dăunători mereilor şi prunelor şi monitorizarea dezvoltării lor capcane cu lumină se recomandă să le plaseze în livadă în perioada sau la sfârşitul înfloririi. Pentru aceasta se recomandă o capcană pentru 3-5 hectare, având în vedere, că raza de atragere a insectelor dăunătoare de către sursa aplicată de putere mică este de aproximativ 250 de metri. Pentru a evita concentrarea insectelor atrase în centrul lotului, capcana e cel mai bine de a o montata la marginea lui suprafeţei pe un suport special la o înălţime de aproximativ 1.7-2.5 metri, care corespunde cu mijlocul coroanei copacilor. În funcţie de tipul de capcane se includ în modul autonom cu o baterie sau se conectează reţeaua de $220 \mathrm{~V}$. Verificarea capturilor se efectuează zilnic, pentru numărarea, evidenţierea şi sistematizarea speciilor capturate. Dacă numărul de fluturi ai viermelui merelor sau prunului e de 1-2 pe zi sau 5-7 în timp de 5 zile se semnalizează necesitatea efectuării la timp a măsurilor de protecţie (prelucrări cu insecticide destul 1-2 pentru prima generaţie).

\section{comune:}

Schema tehnologică de utilizare a capcanelor prezintă următoarele operaţiuni

- amplasarea dispozitivelor pe câmpul protejat conform recomandărilor;

- pregătirea şi conectarea dispozitivelor la sursa de alimentaţie cu energie electrică;

- alegerea regimului de lucru a dispozitivelor;

- colectarea materialului biologic-insectelor capturate şi schimbul vasului de colectare;

- separarea insectelor capturate de lichidul conservant şi expunerea lor la păstrare

- analiza capturi şi identificarea speciilor insectelor capturate;

- introducerea datelor în jurnalul de înregistrare a numărului de insecte dăunătoare capturate;

- determinarea gradului de depăşire a pragului economic de dăunare (PED) şi semnalizarea, în cazul când acest indiciu este mai mare, termenului de efectuare a măsurilor de protecţie.

Pentru efectuarea supravegherilor pe câmpurile protejate, capcanele cu lumină se plasează uniform în aşa mod, ca în funcţie de raza de acoperire a sursei de lumină ele asigură atracţia insectelor dăunătoare aflate în zona dată, în special, pentru a semnaliza 
existenţa focarelor de răspândire a dăunătorilor. Pentru aceasta densitatea amplasării capcanelor-este de ajuns una la un hectar. Însă, la culturile înalte (floarea-soarelui, porumb) plasarea capcanelor cu lumină este extrem de dificilă din cauza complexităţii de trecere peste câmp. Activitatea intensivă de zbor a fluturilor din familia Noctuidae dă posibilitate de a controla prezenţa şi densitatea populaţiilor din afara zonei cultivate. Prin urmare, pentru a reduce intensitatea muncii fără a pierde eficacitatea procesului de capturare a dăunătorilor, capcanele pot fi amplasate alături în apropierea imediată a plantaţiilor. Pentru aceasta capcanele se vor monta pe un suport de o înălţime de 1,5-2 m, condiţie în care acţiunea surse de lumină va fi satisfăcătoare. Capcanelor cu lumină utilizate la alte culturi de câmp se plasează în locuri potrivite după schema determinată. În aceste condiţii este raţional de a utiliza capcane cu sursă de alimentaţie autonomă. Colectările de insecte capturate se analizează zilnic şi se identifică speciile şi indicii lor numerici, după care se descrie dinamica de zbor a principalilor dăunători în funcţie de factorii biotici şi abiotici.

Analiza sistematică a materialului capturat, monitorizarea fenologie dezvoltării dăunătorului arată, că zborul masiv a insectelor corespunde întotdeauna cu depunerile în masă a ouălor în natură. Prin urmare, având în vedere condiţiile de temperatură în timpul acestei perioade de timp, se poate determina termenii efectuării tratamentelor chimice. Este important să se determine maximă de zbor a femelelor tinere deoarece anume cu ele este legată depunerea în masă a ouălor şi ecluzarea omizilor dăunătorului.

Pentru capturarea în masă a insectelor dăunătoare cu scopul diminuării populaţiilor lor se recomandă de asemenea utilizarea capcanelor cu lumină ultravioletă, însă este necesar de a mări densitatea lor până la 4 capcane la hectar, fiind amplasate în ordinea de şah.

Aplicarea capcanelor cu lumină ultravioletă pentru capturarea sistematică a insectelor dăunătoare aduce la reducerea substanţială a indiciilor numerici ai populaţiei dăunătorilor şi creează condiţii pentru sporirea eficienţei insectelor benefice, atât a celor din natură cât şi a celor lansate cu scopul reglării densităţii dăunătorilor sub nivelul pragului economic de dăunare (PED). Toate acestea vor contribui la reducerea cu circa $30 \%$ a tratamentelor chimice [2 ] şi la obţinerea producţiei agricole de o calitate înaltă.

\section{Condiţiile de exploatare a capcanelor}

Pentru a stabili începutul zborului în dinamică a dăunătorilor şi determina termenii de tratare este suficient de a include capcana cu lumina timp de 2-3 ore după apusul soarelui. Iar pentru controlul dăunătorilor capcanele se includ peste noapte începând cu orele 22 şi se deconectează după miezul nopţii la orele 3. În caz când capcana este înzestrată cu fotosensor ea funcţionează în mod automat în funcţie de timpul întunecos al diurnei. Intensitatea de zbor a insectelor mult depinde şi de nivelul temperaturii aerului în timpul nopţii. La temperaturi înalte se măreşte şi numărul de insecte capturate, la temperaturi sub $14{ }^{\circ}$ numărul dăunătorilor capturaţi se reduce brusc.

\section{Recomendări de implementare și utilzare a capcanelor cu lumină}

Pe baza datelor obţinute în procesul testărilor în câmp s-au elaborat instrucţiuni pentru implementarea şi utilizarea capcanelor cu lumină în producere şi utilizarea lor în calitate de elemente a sistemelor de protecţie integrată a plantelor. Dispozitivele elaborate se recomandă pentru utilizare atât în scopuri ştiinţifice la efectuarea colectărilor faunistice, cât şi pentru semnalizarea, monitorizarea şi diminuarea densităţii populaţiilor dăunătorilor culturilor agricole prin capturarea lor în masă.

Capcanele cu lumină ultravioletă sunt recomendate Direcţiilor Raionale pentru Siguranţă Alimentară pentru semnalizarea, monitorizarea şi elaborarea prognozelor de dezvoltăre a dăunătorilor culturilor agricole corespunzătoare, care vor contribui la 
perfecţionarea măsurilor de protecţie în zonele respective ale Republicii Moldova și efectuarea acestora la momentul rezonabil.

\section{Bibliografie}

1.ПРИСТАВКО В.П. Суточная активность лета и дальность миграции бабочек яблонной плодожорки в степной и лесостепной зонах Украины // Зоол. журн.- 1971. Т.50, вып. 11

2. БЛЯГОЗ А.М. Обоснование типа источника-аттрактанта для электрооптического преобразователя защиты растений / Блягоз А.М., Газалов В.С.//Энергосберегающие технологии. Проблемы их эффективного использования: материалы междунар. науч. - практ. конф. 11-12 дек. 2007 г. - Волгоград, 2008. - С. 99 101. 